\title{
Branched Chain Amino Acid Metabolism in the Retina of Diabetic Rats
}

\author{
R. Frayser and M. G. Buse \\ Departments of Medicine and Biochemistry, Medical University of South Carolina, Charleston, South Carolina, USA
}

\begin{abstract}
Summary. Diabetes is known to produce increased levels of the branched chain amino acids in plasma, heart and muscle as well as increased oxidation of $\left[{ }^{14} \mathrm{C}\right]$-leucine by nerves and muscles from rats. Plasma and retinas from streptozotocin diabetic rats had significant elevations in branched chain amino acid levels compared to control. Retinas from diabetic rats have been found to oxidize significantly more of the branched chain amino acids, leucine, isoleucine and valine than did control retinas when incubated in media containing $16.5 \mathrm{mmol} / \mathrm{l}$ glucose. Neither the extracellular space nor the tissue pool of leucine was significantly different in the two groups. The addition of 19 amino acids, at normal plasma concentrations, to the incubation media resulted in 80 percent suppression of leucine oxidation without significant change in incorporation of $\left[{ }^{14} \mathrm{C}\right]$ into protein. These results suggest that the major role for the branched chain amino acids in the rat retina is in protein synthesis which is not affected by short-term diabetes.
\end{abstract}

Key words: Retinal metabolism, amino acids, leucine, isoleucine, valine, streptozotocin, diabetes.

In moderate to severe, untreated diabetes, the branched chain amino acids leucine, isoleucine, and valine are elevated in plasma, heart [1] and muscle [2]. Their concentration is unchanged in the sciatic nerve [3]. These are the only essential amino acids which are metabolized primarily outside the liver. Significant increases in the ability to oxidize leucine have been found in nerve [3] and muscle [4] from diabetic animals.

The retina can metabolise amino acids and significant levels of free amino acids have been found in the rat retina by Pasantes-Morales et al [5]. Macaione et al [6] reported changes in the free amino acid pattern of rat retinas at various developmental stages. Changes in retinal amino acids have been found in retinitis pigmentosa [7] and dystrophic retinas [8].

To our knowledge, no one has examined the capacity of the diabetic retina to metabolise the branched chain amino acids nor compared the level of free amino acids in the diabetic retina with normal retinas.

\section{Methods and Materials}

Male rats of the Wistar strain weighing $120-200 \mathrm{~g}$ were used. The animals had free access to food and water up to the time of the experiment. Control and experimental rats were matched by weight prior to the induction of diabetes via a single intraperitoneal injection of streptozotocin $(100-120 \mathrm{mg} / \mathrm{kg})$. Streptozotocin was kindly supplied by Dr. William Dulin, Upjohn Research Laboratories, Kalamazoo, Michigan.

Urinary glucose and ketones were estimated by glucose oxidase (Test Tape Eli Lilly Co., Indianapolis, Indiana) and by the nitroprusside reaction (Acetest tablets, Ames Co., Elkhart, Indiana) respectively. Plasma glucose was measured by Autoanalyzer (Technicon Instruments Co., Tarrytown, N. Y.) using a method based on the reduction of ferricyanide.

Rats were sacrificed five days after injection of streptozotocin by decapitation with a guillotine. Diabetic animals were included only if they had a $4+$ glucosuria, the concentration of glucose in the plasma exceeded $16.5 \mathrm{mmol} / \mathrm{l}$, and if they had lost weight or gained less than $5 \mathrm{~g}$ in the five days. 
The eyes were enucleated and the retinas removed within two minutes of decapitation. For metabolic studies, each retina was incubated separately in one $\mathrm{ml}$. Krebs-Ringer bicarbonate buffer containing $0.1 \mathrm{mmol} / \mathrm{l}$ leucine or other amino acids and glucose as indicated, equilibrated with oxygen and carbon dioxide $(95: 5), \mathrm{pH} 7.4$ at $37^{\circ} \mathrm{C}$ in a Dubnoff metabolic shaker. The retinas were preincubated for 30 minutes and incubated for two hours in identical media except that the $\left[1-{ }^{14} \mathrm{C}\right]$-amino acid tracers (leucine, isoleucine or valine) were added during incubation only. At the end of incubation trichloroacetic acid was injected into the reaction vessel, the ${ }^{14} \mathrm{CO}_{2}$ generated was trapped in Hyamine and counted in a liquid scintillation spectrometer [4]. The precipitated tissues were homogenized and washed with ethanol, then with di-isopropyl ether and dried. Protein was digested in $1 \mathrm{~mol} / 1 \mathrm{NaOH}$ and samples removed for protein determination by the method of Lowry et al [9] using crystalline bovine albumin standards. A portion was solubilized in BioSolv (Beckman Instruments, Inc., Palo Alto, California) and counted in the liquid scintillation spectrometer for calculation of $\left[{ }^{14} \mathrm{C}\right]$ incorporation into protein. Intracellular water was estimated in diabetic and control retinas following incubation in buffer containing $2 \mu \mathrm{Ci} / \mathrm{ml}\left[{ }^{14} \mathrm{C}\right]$-urea and $4 \mu \mathrm{Ci} / \mathrm{ml}\left[{ }^{3} \mathrm{H}\right]$-mannitol.

A separate set of experiments was undertaken to determine the amino acid concentrations of diabetic and control retinas. Because of the small size of the rat retina, six retinas were pooled for amino acid and protein determinations. These retinas were rapidly removed from the enucleated eyes and immediately frozen in liquid nitrogen. The pooled retinas ware homogenized in $4 \mathrm{ml}$ of sulphosalicyclic acid $(5 \mathrm{~g} / 100 \mathrm{ml})$ at $4^{\circ}$ with a Polytron tissue homogenizer (Brinkmann Instruments Inc., Westbury, N.Y.). The precipitate was saved for protein analysis. The supernatant was filtered through ultrafiltration membrane cones (Centriflo No. 2100, CF-50, Amicon Corp., Lexington, MA). After adjusting the $\mathrm{pH}$ to 2.2 the amino acids in the ultrafiltrate were measured by ion exchange chromatography using a Beckman Model 121 amino acid analyzer with an expanded sensitivity attachment. A single column system for physiological fluids was used, consisting of $0.9 \times 30 \mathrm{~cm}$ column of DC-6A Durrum resin, five lithium carbonate buffers (PicoBuffer System IV, Pierce Co., Rockford, Ill.), and one temperature change [3]. Plasma amino acid concentrations were determined using the same system. External standards containing all the amino acids were run between two and three unknown samples.

In order to establish that the intracellular leucine pool was similar in both groups during incubation, the amino acid content of diabetic and control retinas was also determined following incubation for two hours in buffer containing $0.1 \mathrm{mmol} / \mathrm{l}$ leucine $+16.5 \mathrm{mmol} / \mathrm{l}$ glucose.

Because glutamate and glutamine may be degraded during chromatography, these amino acids were measured fluorometrically $[10,11]$ for both retina and plasma.

Means \pm SEM are tabulated. Comparisons between means were made by Student's $\mathrm{t}$ test. $\left[{ }^{14} \mathrm{C}-1\right]$ labelled branched chain amino acids (sp. act $50 \mathrm{mCi} / \mathrm{mmol}$ ) were purchased from New England Nuclear Corp., Boston, Mass. (leucine and valine) and from Calatomic Corp., Los Angeles, Calif. (isoleucine).

\section{Results}

Plasma glucose was $7.9 \pm 0.03 \mathrm{mmol} / \mathrm{l}$ in control and $26.7 \pm 1.6$ in the diabetic rats. Urine and plasma were negative or $1+$ for ketones. Similar intracellular levels of leucine were found in retinas from diabetic and control rats after incubation with $0.1 \mathrm{mmol} / 1$ leucine for one hour $(461 \pm 40 \mathrm{nmol} / \mathrm{mg}$ protein). No significant difference was found between diabetic and control retinal extracellular space measured as the space of distribution of $0.1 \mathrm{mmol} / 1\left[{ }^{3} \mathrm{H}\right]$-mannitol.

The free amino acid concentrations of retinas from diabetic and control animals and plasma are detailed in Table 1. Compared with the control, the retinas from diabetic animals showed significantly decreased concentrations of threonine $(48 \%)$, tyrosine $(35 \%)$, histidine $(59 \%)$, lysine $(31 \%)$, and glutamate $(22 \%)$. Significant increases were found in the branched chain amino acids leucine $(105 \%)$, valine $(111 \%)$, and isoleucine $(26 \%)$. The other amino acids were not significantly different. Significantly reduced concentrations of alanine $(66 \%)$, aspartate $(32 \%)$, threonine $(26 \%)$, tyrosine $(16 \%)$, lysine $(43 \%)$, histidine $(23 \%)$, and arginine $(33 \%)$, were found in plasma from diabetic animals compared to control; valine $(96 \%)$, isoleucine $(72 \%)$, leucine $(69 \%)$, and ornithine $(17 \%)$ levels were significantly elevated.

When incubated with $16.5 \mathrm{mmol} / \mathrm{l}$ glucose and $0.1 \mathrm{mmol} / 1\left[1-{ }^{14} \mathrm{C}\right]$-leucine, retinas from diabetic rats oxidised $25 \%$ more $\left[{ }^{14} \mathrm{C}\right]$-leucine than retinas from control animals $(p<0.01)$ with no significant difference in incorporation into protein (Table 2). In $5.5 \mathrm{mmol} / 1$ glucose, retinal tissues from control animals oxidised $25 \%$ more leucine $(\mathrm{p}<0.001)$ than when the concentration of glucose was $16.6 \mathrm{mmol} / \mathrm{l}$. Leucine oxidation by retinas of diabetic rats was not 
Table 1. The effect of streptozotocin diabetes on amino acid concentrations of retina and plasma

\begin{tabular}{|c|c|c|c|c|}
\hline & \multicolumn{2}{|c|}{$\begin{array}{l}\text { Concentration in Retina } \\
\mu \mathrm{mol} / \mathrm{mg} \text { protein }\end{array}$} & \multicolumn{2}{|c|}{$\begin{array}{l}\text { Concentration in Plasma } \\
\mu \mathrm{mol} / \text { litre }\end{array}$} \\
\hline & Control & Diabetes & Control (6) & Diabetic (4) \\
\hline Taurine & $58.4 \pm 4.3(8)$ & $60.4 \pm 4.3(7)$ & $151 \pm 4.4$ & $149 \pm 7.8$ \\
\hline Aspartate & $2.33 \pm 0.14(7)$ & $2.05 \pm 0.07(7)$ & $23 \pm 0.8$ & $16 \pm 1.5^{\mathrm{a}}$ \\
\hline Threonine & $0.38 \pm 0.01(7)$ & $0.20 \pm 0.01(7)^{\mathrm{a}}$ & $401 \pm 22.9$ & $297 \pm 12.1^{\mathrm{a}}$ \\
\hline Serine & $0.50 \pm 0.03(7)$ & $0.37 \pm 0.02(6)$ & $218 \pm 8.8$ & $164 \pm 7.4$ \\
\hline Glutamate & $0.12 \pm 0.01(2)$ & $0.10 \pm 0.01(2)^{a}$ & $121 \pm 9.3$ & $107 \pm 6.4$ \\
\hline Glutamine & $0.05 \pm 0.01(2)$ & $0.04 \pm 0.01(2)$ & $846 \pm 32.0$ & $712 \pm 22.6^{\mathrm{a}}$ \\
\hline Glycine & $2.98 \pm 0.09(7)$ & $2.18 \pm 0.49$ & $219 \pm 6.4$ & $261 \pm 16.0$ \\
\hline Alanine & $0.86 \pm 0.05(7)$ & $0.82 \pm 0.01(7)$ & $308 \pm 3.5$ & $106 \pm 9.5^{\mathrm{a}}$ \\
\hline Valine & $0.18 \pm 0.01(8)$ & $0.38 \pm 0.01(7)^{\mathrm{a}}$ & $202 \pm 19.1$ & $396 \pm 20.1^{a}$ \\
\hline Methionine & $0.10 \pm 0.01(8)$ & $0.08 \pm 0.01(6)$ & $57 \pm 1.0$ & $50 \pm 1.0$ \\
\hline Isoleucine & $0.19 \pm 0.01(8)$ & $0.24 \pm 0.01(7)^{\mathrm{a}}$ & $91 \pm 5.0$ & $156 \pm 7.9^{a}$ \\
\hline Leucine & $0.18 \pm 0.01(8)$ & $0.37 \pm 0.01(7)^{\mathrm{a}}$ & $185 \pm 6.1$ & $311 \pm 7.2^{\mathrm{a}}$ \\
\hline Tyrosine & $0.40 \pm 0.01(7)$ & $0.26 \pm 0.02(7)^{\mathrm{a}}$ & $45 \pm 0.2$ & $37 \pm 7.2^{a}$ \\
\hline Ornithine & $0.10 \pm 0.01(7)$ & $0.10 \pm 0.02(6)$ & $32 \pm 0.6$ & $37 \pm 0.6^{a}$ \\
\hline Lysine & $0.64 \pm 0.03$ & $0.44 \pm 0.03(5)^{\mathrm{a}}$ & $203 \pm 15.1$ & $115 \pm 8.9^{\mathrm{a}}$ \\
\hline Histidine & $0.12 \pm 0.01(8)$ & $0.05 \pm 0.01(5)^{\mathrm{a}}$ & $80 \pm 2.4$ & $62 \pm 1.5^{\mathrm{a}}$ \\
\hline Arginine & $0.31 \pm 0.02(8)$ & $0.27 \pm 0.01(7)$ & $139 \pm 7.6$ & $93 \pm 1.8^{\mathrm{a}}$ \\
\hline
\end{tabular}

( ) Number of experiments. For retinas, each experimental point contained six pooled retinas. Glutamine and glutamate assays done flurometrically on a pool of 2 retinas. Plasma from 4 animals was pooled for each plasma experiment a $\mathrm{p}<0.01$

Table 2. Effect of diabetes, glucose and insulin on the oxidation and incorporation into protein of $1-{ }^{14} \mathrm{C}$ leucine by the isolated retina

\begin{tabular}{|c|c|c|c|c|c|c|}
\hline & \multicolumn{3}{|c|}{$\begin{array}{l}{ }^{14} \mathrm{CO}_{2} \text { Produced } \\
\mathrm{DPM} / \mathrm{mg} \text { protein } / 2 \mathrm{~h}\end{array}$} & \multicolumn{3}{|c|}{$\begin{array}{l}{ }^{14} \mathrm{C} \text { Incorporated into protein } \\
\mathrm{DPM} / \mathrm{mg} \text { protein } / 2 \mathrm{~h}\end{array}$} \\
\hline & Control & Diabetic & $\begin{array}{l}\text { Control vs } \\
\text { diabetic (p) }\end{array}$ & Control & Diabetic & $\begin{array}{l}\text { Control vs } \\
\text { diabetic (p) }\end{array}$ \\
\hline $5.5 \mathrm{mmol} / \mathrm{/}$ glucose & $6502 \pm 186(14)$ & $5887 \pm 270(15)$ & N.S. & $2864 \pm 107$ & $2608 \pm 235$ & N.S. \\
\hline $16.5 \mathrm{mmol} / 1$ glucose & $5106 \pm 208(16)$ & $6423 \pm 244(18)$ & $<0.001$ & $2624 \pm 84$ & $2339 \pm 173$ & N.S. \\
\hline glucose effect & $p<0.001$ & N.S. & & N.S. & N.S. & \\
\hline $16.5 \mathrm{mmol} / \mathrm{l}$ glucose & $5412 \pm 222(7)$ & $6625 \pm 186(11)$ & $<0.001$ & $2521 \pm 151$ & $2248 \pm 219$ & N.S. \\
\hline $16.5 \mathrm{mmol} / 1$ glucose & $4418 \pm 342(8)$ & $5714 \pm 400(12)$ & $<0.025$ & $2824 \pm 275$ & $2912 \pm 200$ & N.S. \\
\hline plus $1 \mathrm{~m}$ unit insulin & $18 \% \downarrow$ & $14 \% \downarrow$ & & & & \\
\hline insulin effect & $<0.05$ & $<0.05$ & & N.S. & N.S. & \\
\hline
\end{tabular}

Retinas were preincubated for 30 minutes in $1 \mathrm{ml} \mathrm{Krebs-Ringer} \mathrm{bicarbonate} \mathrm{buffer} \mathrm{containing} 0.1 \mathrm{mmol} / 1 \mathrm{~L}$-Leucine and the appropriate glucose and insulin concentrations, then transferred into media of identical volume and composition containing $\mathrm{L}-\left[1-{ }^{14} \mathrm{C}\right]-1$ eucine, 0.02 $\mu \mathrm{Ci} / \mathrm{ml},(44,400 \mathrm{dpm} / \mathrm{ml})$ and incubated for 2 hours at $37^{\circ}, \mathrm{pH} 7.4$ with a gas phase of $\mathrm{O}_{2}+\mathrm{CO}_{2},(95: 5)$

( ) number of retinas

affected by the threefold change in glucose concentration. The addition of $1 \mathrm{mU} / \mathrm{ml}$ insulin to the incubation medium containing $16.5 \mathrm{mmol} / \mathrm{l}$ glucose resulted in an $18 \%$ decrease in ${ }^{14} \mathrm{CO}_{2}$ production by control retinas $(p<0.05)$ and a $14 \%$ reduction $(p<0.05)$ in retinas from diabetic animals with no change in the amount of $\left[{ }^{14} \mathrm{C}\right]$ incorporated into protein. Retinas from diabetic animals oxidised more leucine than the control retinas in the presence or absence of insulin. No consistent effect of insulin on leucine oxidation could be demonstrated when retinas were incubated in $5.5 \mathrm{mmol} / \mathrm{l}$ glucose.
In control retinas the production of ${ }^{14} \mathrm{CO}_{2}$ from $\left[{ }^{14} \mathrm{C}\right]$ valine (Table 3$)$ was $39 \%$ less $(\mathrm{p}<0.001)$ and from $\left[{ }^{14} \mathrm{C}\right]$ isoleucine $52 \%$ less $(\mathrm{p}<0.001)$ than the ${ }^{14} \mathrm{CO}_{2}$ produced by the oxidation of $\left[{ }^{14} \mathrm{C}\right]$ leucine. Retinas from diabetic animals showed a similar pattern for oxidation of the three branched chain amino acids. Retinas from diabetic rats consistently oxidised more of any branched chain amino acid than did retinas isolated from control rats. Approximately $30 \%$ more $\left[{ }^{14} \mathrm{C}\right]$ was incorporated into protein from valine or isoleucine than from leucine.

The addition to the incubation media of a mix- 
Table 3. Comparison of the oxidation and incorporation into protein of the branched chain amino acids

\begin{tabular}{|c|c|c|c|c|c|c|}
\hline & \multicolumn{3}{|c|}{$\begin{array}{l}{ }^{14} \mathrm{CO}_{2} \text { Produced } \\
(\mathrm{DPM} / \mathrm{mg} \text { protein/2h) }\end{array}$} & \multicolumn{3}{|c|}{$\begin{array}{l}{ }^{14} \mathrm{C} \text { Incorporated into protein } \\
(\mathrm{DPM} / \mathrm{mg} \text { protein/2h) }\end{array}$} \\
\hline & Control & Diabetic & $\begin{array}{l}\text { Control vs } \\
\text { diabetic (p) }\end{array}$ & Control & Diabetic & $\begin{array}{l}\text { Control us } \\
\text { diabetic (p) }\end{array}$ \\
\hline $\begin{array}{l}16.5 \mathrm{mmol} / 1 \text { glucose } \\
\text { plus } 0.1 \mathrm{mmol} / 1 \text { leucine } \\
16.5 \mathrm{mmol} / 1 \text { glucose }\end{array}$ & $5146 \pm 277(10)$ & $6412 \pm 237(12)$ & $<0.001$ & $2525 \pm 93$ & $2646 \pm 147$ & N.S. \\
\hline $\begin{array}{l}\text { plus } 0.1 \mathrm{mmol} / 1 \text { isoleucine } \\
16.5 \mathrm{mmol} / 1 \text { glucose }\end{array}$ & $2462 \pm 200(8)$ & $3572 \pm 139(8)$ & $<0.001$ & $3496 \pm 113$ & $3999 \pm 143$ & N.S. \\
\hline plus $0.1 \mathrm{mmol} / \mathrm{l}$ valine & $3139 \pm 235(7)$ & $4582 \pm 271(7)$ & $<0.001$ & $3667 \pm 120$ & $3978 \pm 200$ & N.S. \\
\hline
\end{tabular}

Retinas were preincubated 30 minutes in $1 \mathrm{ml}$ Krebs-Ringer bicarbonate buffer containing $16.5 \mathrm{mmol} / 1 \mathrm{glucose}+0.1 \mathrm{mmol} / 1 \mathrm{amino}$ acid, then transferred into media of identical volume and composition containing the $\mathrm{L}\left[1-{ }^{14} \mathrm{C}\right]$-amino acid $(0.02 \mathrm{Ci} / \mathrm{ml}),(44$, $400 \mathrm{dpm} / \mathrm{ml}$ ) and incubated 1 hour at $37^{\circ} \mathrm{C}, \mathrm{pH} 7.4$ with a gas phase of $\mathrm{O}_{2}$ and $\mathrm{CO}_{2}(95: 5)$

( ) number of retinas

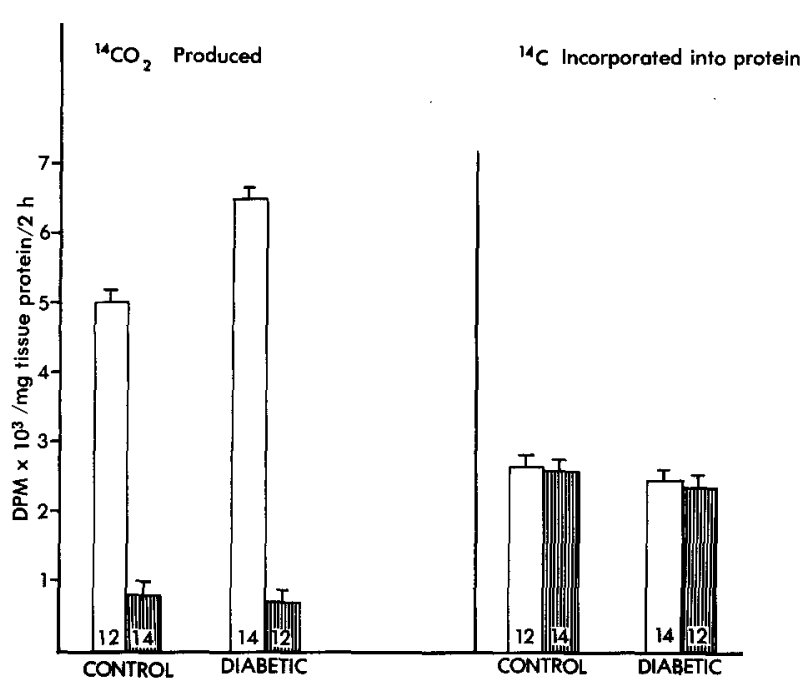

Fig. 1. The effect of plasma amino acids on leucine metabolism. Retinas were preincubated 30 minutes in $1 \mathrm{ml}$ Krebs Ringer bicarbonate buffer containing $16.5 \mathrm{mmol} / \mathrm{l}$ glucose and $0.1 \mathrm{mmol} / 1$ leucine and then incubated 2 hours in identical media containing $0.02 \mu \mathrm{Ci}\left[{ }^{14} \mathrm{C}\right]$ leucine $(44,400 \mathrm{dpm} / \mathrm{ml})(\square$, basal media) or 19 amino acids at normal plasma concentration m at $37^{\circ} \mathrm{C}$ in an atmosphere of oxygen and carbon dioxide (95:5). Number in bar is number of experiments

ture of 19 amino acids at concentrations found in the serum of fed rats [1] reduced leucine oxidation to less than $20 \%$ of the quantity oxidized when either control retinas or retinas from diabetic animals were incubated with media containing only glucose $+{ }^{14} \mathrm{C}$-leucine (Fig. 1). Figure 2 indicates that most of the suppression of leucine oxidation was probably caused by the presence of glutamine and glutamate.

\section{Discussion}

Our values for free amino acid concentrations in the normal rat retina are in general agreement with

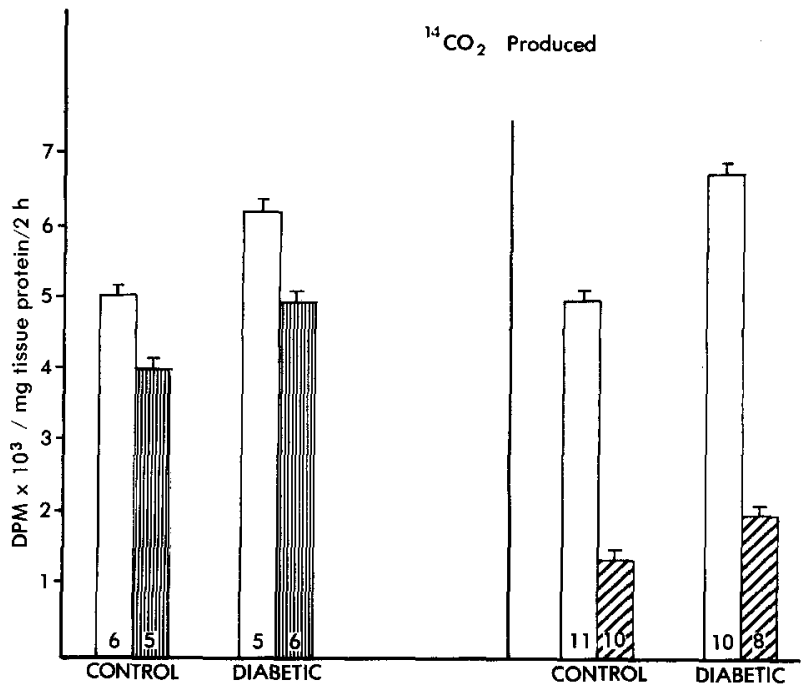

Fig. 2. ${ }^{14} \mathrm{CO}_{2}$ production from $\left[{ }^{14} \mathrm{C}\right]$ leucine. Retinas were preincubated 30 minutes in $1 \mathrm{ml}$ Krebs Ringer bicarbonate buffer containing $16.5 \mathrm{mmol} / \mathrm{l}$ glucose and $0.1 \mathrm{mmol} / \mathrm{l}$ leucine and then incubated for 2 hours in identical buffer containing $0.02 \mu \mathrm{Ci}(44$, $400 \mathrm{dpm} / \mathrm{ml}\left[{ }^{14} \mathrm{C}\right]$ leucine ( $\square$, basal media) plus either $0.35 \mathrm{mmol} / \mathrm{l}$ aspartate $+0.07 \mathrm{mmol} / \mathrm{l}$ asparagine (証) or $0.35 \mathrm{mmol} / \mathrm{l}$ glutamine $+0.20 \mathrm{mmol} / 1$ glutamate 2 at $37^{\circ} \mathrm{C}$ in an atmosphere of oxygen and carbon dioxide $(95: 5)$. Number in bar is number of experiments

those in the literature $[5,6]$. The changes associated with diabetes are generally in the same direction in the plasma and the retina. Tyrosine, threonine, histidine and lysine decreased significantly in plasma and retina while the three branched chain amino acids increased markedly $(p<0.01)$. The origin of the increased circulating branched chain amino acids which accompany diabetes is not well understood. Such changes have been documented extensively in man [12]. Bloxam [13] observed similar decreases in the concentration of several amino acids in plasma of diabetic rats. His data suggest increased extraction of a number of amino acids by the diabetic liver. 
While decreased plasma alanine is not always associated with uncompensated diabetes in man [12] or in the rat [1] it has been previously observed in diabetic rats [13] and in man $[14,15]$. Hypoalaninaemia associated with diabetes is probably caused by increased hepatic alanine uptake which is not compensated by increased alanine release from muscle [15].

While the free amino acid content of the retina from diabetic animals showed generally parallel changes with those occurring in plasma, sciatic nerves of diabetic rats showed essentially no change in the concentration of the amino acids except for the marked decrease in glutamine [3]. Thus it seems that the retina equilibrates more readily with the plasma amino acids than does the peripheral nerve.

The values obtained for retinal oxidation of $\left[{ }^{14} \mathrm{C}\right]$ leucine are in agreement with those obtained for isolated sciatic nerve [3]; they are lower than the values for isolated muscle, heart, and aorta [16]. Since the retina is not a homogenous tissue, it is not possible to speculate which of its constituent cell types are responsible for the observed changes in the course of short-term diabetes.

The present data indicate that the isolated rat retina has a capacity for oxidising leucine, isoleucine and valine. As in muscle, oxidation of these compounds appears to be regulated in a parallel fashion. Increased ${ }^{14} \mathrm{CO}_{2}$ production from $\left[1-{ }^{14} \mathrm{C}\right]$-leucine could be the result of accelerated leucine transport into the cells, stimulation of a rate limiting reaction of leucine oxidation (e. g. transamination or oxidative decarboxylation of the resulting $\alpha$ - keto acid), or increased labelling of the tissue pool of free leucine due to a decrease in pool size or accelerated $\left[{ }^{14} \mathrm{C}\right]$-leucine transport into the cells. Before incubation, the pool of branched chain amino acids in retinas of diabetic rats was actually increased. Neither the extracellular space nor the tissue pool of leucine after incubation were significantly different in retinas from diabetic or control rats. Amino acid transport into cells is generally increased by insulin and not by insulin deficiency. It would thus seem likely that the increased ${ }^{14} \mathrm{CO}_{2}$ production from leucine represents accelerated oxidation of the amino acid by some structure in the retina of diabetic rats.

When incubated in the presence of $16.5 \mathrm{mmol} / \mathrm{l}$ glucose the retinas from diabetic animals oxidised amino acids faster than the control retinas. The need for elevated glucose concentrations in the media to demonstrate the effect of diabetes on leucine oxidation is similar to that seen in peripheral nerve [3]. In streptozotocin diabetic animals, retinal glucose levels have been found to be 4-5 times normal [17] and are directly related to plasma glucose levels
[18]. It is possible that the effect of diabetes on leucine oxidation by the retina is mediated through an impairment of glucose metabolism or glucose transport. The observation that pyruvate, the product of glycolysis, inhibits branched chain amino acid oxidation by several tissues including sciatic nerves and spinal cords, may be relevant in this context [16].

The present findings suggest that, although the retina has the capacity to decarboxylate leucine and the other branched chain amino acids, the reaction proceeds relatively slowly in the presence of physiological concentrations of the other amino acids, particularly glutamate and glutamine. In the latter situation the rate of leucine oxidation is only one third that of its incorporation into proteins. Thus the major role for branched chain amino acids in the retina is presumably in protein synthesis which is not affected by short-term diabetes or the medium glucose concentration.

This investigation was supported by a grant-in-aid from FightFor-Sight, Inc., New York City, and by USPHS grant AM02001 from the National Institute of Arthritis, Metabolism and Digestive Diseases.

\section{References}

1. Scharff, R., Wool, I. G.: Accumulation of amino acids in muscle of perfused rat heart. Effect of insulin. Biochem. J. 97, 257-271 (1965)

2. Odessey, R., Goldberg, A.L.: Oxidation of leucine by rat skeletal muscle. Am. J. Physiol. 223, 1376-1383 (1972)

3. Buse, M. G., Herlong, H.F., Weigand, D. A., Spicer, S. S.: The effect of diabetes, insulin and Wallerian degeneration on leucine metabolism of isolated rat sciatic nerve. J. Neurochem. 29, 1339-1345 (1976)

4. Buse, M. G., Herlong, H.F., Weigand, D. A.: Leucine oxidation by muscles and nerves of diabetic rats. Diabetes 23, 366 (1974)

5. Pasantes-Morales, H., Klethi, J., Ledig, M., Mandel, P.: Free amino acids of chicken and rat retina. Brain Res. 41, 494-497 (1972)

6. Macione, S., Ruggeri, P., DeLuca, F., Tucci, G.: Free amino acids in the rat retina. J. Neurochem. 22, 887-891 (1974)

7. Brotherton, J.: Studies on the metabolism of rat retina with special reference to retinitis pigmentosa. Exp. Eye Res. 1, 246-252 (1962)

8. Cohen, A.I., McDaniel, M., Orr, H.: Absolute levels of some free amino acids in normal and biologically fractionated retinas. Invest. Ophthalmol. 12, 686-693 (1973)

9. Lowry, O.H., Rosebrough, N.H., Farr, A.L., Randall, J. Protein measurement with the Folin phenol reagent. J. Biol. Chem. 193, 265-275 (1951)

10. Bergmeyer, H.U.: Methods in Enzymatic Analysis, L-glutamine determination with glutaminase and glutamate dehydrogenase, p. 1719. London, New York: Academic Press 1974

11. Bergmeyer, H. U.: Methods in Enzymatic Analysis, L-glutamate. UV-assay with glutamate dehydrogenase and NAD, p. 1704. London, New York: Academic Press 1974 
12. Felig, P.: Amino acid metabolism in man. Annu. Rev. Biochem. 44, 933-955 (1975)

13. Bloxam, D. L.: Nutritional aspects of amino acid metabolism. The effects of diabetes on blood and liver amino acids in diabetic rats. Br. J. Nutr. 27, 249-259 (1972)

14. Carlstein, A., Hallgren, B., Jagenburg, R., Svamborg, A., Werko, L.: Amino acids and free fatty acids in plasma in diabetes. I. The effect of insulin on arterial levels. Acta Med. Scand. 179, 361-370 (1969)

15. Wahren, J., Felig, P., Cerasi, E., Luft, P.: Splanchnic and peripheral glucose and amino acid metabolism in diabetes mellitus. J. Clin. Invest. 51, 1870-1878 (1972)

16. Buse, M. G., Jursinic, S., Reid, S. S.: Regulation of branched chain amino acid oxidation in isolated muscles, nerves and aortas of rats. Biochem. J. 148, 363-374 (1975)

17. Hutton, J.C., Schofield, P. J., Williams, J.F., Hollows, F. C.: Sorbitol metabolism in the retina: accumulation of pathway intermediates in streptozotocin induced diabetes in the rat. Aust. J. Exp. Biol. Med. Sci. 52, 361-373 (1974)

18. Heath, H., Kang, S. C., Phillippou, D.: Glucose, glucose -6phosphate, lactate and pyruvate content of the retina, blood and liver in streptozotocin diabetic rats. Diabetologia 11, 57-62 (1975)

Received: May 2, 1977,

and in revised form: August 26, 1977

Regina Frayser, Ph.D.

Department of Medicine

Medical University of South Carolina

171 Ashley Avenue

Charleston, SC 29401

USA 